\title{
Direct cloning of sequence tagged microsatellite sites by DNA affinity chromatography
}

\author{
Bertram Brenig* and Gottfried Brem \\ Department of Molecular Animal Breeding, Veterinärstrasse 13, D-8000 Munich 22, FRG
}

Submitted August 16, 1991

Eukaryotic genomes contain classes of simple repeated highly variable mono-, di-, trinucleotide motifs, termed microsatellites (1). One of the most frequent occurring motif is (TG) $)_{n}$ which is present in $5-10 \times 10^{4}$ copies per genome, spaced at intervals of $50-100 \mathrm{~kb}(2)$. Microsatellites are useful for all types of physical mapping procedures, e.g. genome-, chromosome-, cosmid-, YAC-mapping, and DNA fingerprinting. They can be amplified by PCR using primers of the flanking DNA regions which 'nucleates' them to specific loci. Therefore they have been termed 'sequence tagged microsatellite sites' (STMS) (1).

We have used a simple approach for the direct cloning of porcine STMS by DNA affinity chromatography. Porcine DNA was prepared from blood samples according to standard protocols (3). DNA was sonicated to a size range of $0.2-1.6 \mathrm{~kb} .1 .5-20$ $\mathrm{mM}$ poly[dU-dG] was coupled to $4-7 \mathrm{mg}$ dry weight $/ \mathrm{ml}$ reaction volume of CNBr-activated Sepharose 4B (Pharmacia) in $10 \mathrm{mM}$ potassium phosphate $\mathrm{pH} 8.0$ overnight at room temperature (4). DNA-Sepharose was washed on a fritted glass funnel with 10 $\mathrm{mM}$ potassium phosphate $\mathrm{pH} 8.0,1 \mathrm{M}$ potassium phosphate $\mathrm{pH}$ 8.0, $1 \mathrm{M} \mathrm{KCl}, \mathrm{H}_{2} \mathrm{O}, 0.1 \mathrm{M} \mathrm{NaOH}$, and $\mathrm{H}_{2} \mathrm{O}$, until no further absorbance at $260 \mathrm{~nm}$ was released. Finally, the DNA-Sepharose was resuspended in an appropriate volume of TNE buffer (10 mM Tris- $\mathrm{HCl}$ pH 8.0, $100 \mathrm{mM} \mathrm{NaCl}, 1 \mathrm{mM}$ EDTA pH 8.0). DNA-Sepharose was then incubated overnight at $4^{\circ} \mathrm{C}$ with the sonicated porcine DNA which had been denatured by incubation at $95^{\circ} \mathrm{C}$ for $10 \mathrm{~min}$. After annealing of the porcine DNA, the DNA-Sepharose was washed with approx. $400 \mathrm{ml}$ TNE buffer at $4^{\circ} \mathrm{C}$ to remove excess DNA. To release the porcine DNA, DNA-Sepharose was incubated at $4^{\circ} \mathrm{C}$ in $0.1 \mathrm{M} \mathrm{NaOH}$ for 1 $h$ on an end-over-end shaker. The batch was then left at $4^{\circ} \mathrm{C}$ overnight to sediment the DNA-Sepharose. The supernatant was carefully collected and the ssDNA precipitated. SsDNA was converted to dsDNA by random priming using the Random Primers Labeling Kit (BRL) (5) with one exception. Instead of the Klenow enzyme, DNA polymerase I was added to the reaction mixture in order to obtain complete elongation products. After incubation at $37^{\circ} \mathrm{C}$ for $2 \mathrm{~h}$ the reaction mixture was purified through a nick coloumn (Pharmacia). The dsDNA was then directly ligated into the SmaI site of pGEM-4Z (Stratagene) and recombinant plasmids were used to transform E.coli XL1-blue (Stratagene). Transformed XLl-blue were plated, replicas were taken and hybridized with ${ }^{32} \mathrm{P}$-labeled poly[dU-dG] to identify $(\mathrm{CA} / \mathrm{TG})_{\mathrm{n}}$ containing clones. 200 clones (approx. 10\%) hybridized to the probe. 50 colonies were selected randomly and sequenced by standard procedures using the T7 Sequencing Kit (Pharmacia). The average length of the completely independent clones was $150-200$ bp containing $(\mathrm{CA} / \mathrm{TG})_{\mathrm{n}}$ repeats of $6-34$ bp (n 3-17). Comparison of the tag sequences with the EMBL Data Library (Rel. 24) and NucDat\&ProDat (Vers. 3.9) revealed no significant homologies to published sequences.

The described procedure allows the rapid cloning of all kinds of STMS, for example by coupling other commercially available poly-deoxy-nucleotides than poly[dU-dG]. These may serve as potential genetic markers, e.g. for the construction of physical maps.

\section{ACKNOWLEDGEMENTS}

The authors gratefully acknowledge E.-L. Winnacker for providing excellent working conditions in his laboratory. $M$. Karaghiosoff and A. Krause are thanked for valuable experimental advice.

\section{REFERENCES}

1. Beckmann,J.S. and Soller,M. (1990) Bio/Technology 8, 930-932.

2. Stallings,R.L., Torney,D.C., Hildebrand,C.E., Longmire,J.L., Deaven,L.L., Jett,J.H., Doggett,N.A. and Moyzis,R.K. (1990) Proc. Natl. Acad. Sci. USA 87, 6218-6222.

3. Ausubel,F.M., Brent,R., Kingston,R.E., Moore,D.D., Smith,J.A., Seidman,J.G. and Struhl,K. (1987) Wiley \& Sons, New York.

4. Arndt-Jovin,D.J., Jovin,T.A., Bähr,W., Frischauf,A.-M. and Marquardt,M. (1975) Eur. J. Biochem. 54, 411-418.

5. Feinberg,A.P. and Vogelstein,B. (1983) Anal. Biochem. 132, 6-13. 